Research Report 1724

\title{
Full Crew Interactive Simulation Trainer - Bradley (FIST-B): Limited User Assessment
}

\author{
Margaret S. Salter \\ U.S. Army Research Institute
}

Infantry Forces Research Unit

Scott E. Graham, Chief

U.S. Army Research Institute for the Behavioral and Social Sciences 5001 Elsenhower Avenue, Alexandria, Virginia 22333-5600

May 1998 